\title{
Removal of TPH, UCM, PAHs, and Alk-PAHs in oil-contaminated soil by thermal desorption
}

\author{
Byeongwook Choi ${ }^{1}$, Sungjong Lee ${ }^{1}$ and Eun Hea Jho ${ }^{2^{*}}$ (]
}

\begin{abstract}
Oil-contaminated soils from a former landfill and gas station site in Korea were treated by thermal desorption. The removal efficiencies of the different oil components such as total petroleum hydrocarbons (TPH), polyaromatic hydrocarbons (PAHs), unresolved complex mixtures (UCM), and alkylated PAHs (Alk-PAHs) by thermal desorption were determined. The effects of temperatures $\left(200,400\right.$, and $\left.600^{\circ} \mathrm{C}\right)$ and treatment times $(15,30,45$, and $60 \mathrm{~min})$ on the thermal desorption efficiency were studied. The treatment efficiency increased with increasing temperature from 200 to $400^{\circ} \mathrm{C}$ and with increasing treatment time. Almost complete removals of TPH, UCM, PAHs, and Alk-PAHs were observed after $15 \mathrm{~min}$ at $400{ }^{\circ} \mathrm{C}$. The treatment temperatures of 400 and $600{ }^{\circ} \mathrm{C}$ did not show a significant difference ( $p$-value $>0.05$ ). Overall, this study shows that the different components of oil in the oil-contaminated soils can be treated effectively in a relatively short time by thermal desorption, and such high removal efficiency in a relatively short time for the oil-contaminated soils can be of advantage for the treatment of highly contaminated or weathered soils where biological treatment efficiency is low.
\end{abstract}

Keywords: Thermal desorption, Oil-contaminated soil, UCM, TPH, PAH

\section{Introduction}

Oil contamination of soil and groundwater due to various reasons including leaking pipes in industrial complexes and gas stations is regarded as serious environmental and social problems $[1,2]$. Total petroleum hydrocarbons (TPH) are the main constituents of crude oil; thus, they are one of the most common pollutants found in oil-contaminated soils [3]. Polycyclic aromatic hydrocarbons (PAHs), which can also be found in oil-contaminated soils, are one of the crude oil components harmful to organisms. Structurally, PAHs have two or more fused aromatic rings with a pair of carbon atoms shared between rings in the molecules. They are often found in the atmospheric, soil, and water environments mostly due to anthropogenic activities [4]. They are not easily degraded in natural environment. PAHs have bioaccumulation potential, mutation potential, and

\footnotetext{
*Correspondence: ejho001@jnu.ac.kr

2 Department of Agricultural and Biological Chemistry, Chonnam National University, 77 Yongbong-ro, Buk-gu, Gwangju 61186, South Korea Full list of author information is available at the end of the article
}

carcinogenicity, hence they can be very harmful to living organisms [5]. PAHs can be alkylated and alkylated PAHs (Alk-PAHs) are more toxic than PAHs [6]. A large part of the hydrocarbons in crude oil cannot be identified and this part is referred to as unresolved complex mixture (UCM) hydrocarbons and UCM hydrocarbons are predominant in the environment, for example, in long-term weathered oil-contaminated soils, due to its resistance to natural weathering processes [7]. Previous study also reported toxic effects of UCM on benthic organisms [8]. However, studies reporting on the removal of UCM are very limited.

Remediation of oil-contaminated soils have often involved biological processes such as landfarming, bioremediation, and soil washing with surfactant-producing bacteria [9-11], but the remediation efficiency is relatively low and the treatment period is relatively long [12]. For example, in one previous study, the highest TPH removal rate of $80 \%$ was obtained after the biological treatment of an oil-contaminated soil by supplying microorganisms and various nutrients for $175 \mathrm{~d}$ [13]. 
Another study reported the TPH removal efficiency of $79 \%$ in the Kuwaiti oil-contaminated soil by the 16 $\mathrm{d}$-sequential biowashing and biopile processes [11]. With PAHs, $89 \%$ removal of PAHs by biodegradation took $129 \mathrm{~d}$ [14]. Among various remediation techniques for oil-contaminated soils such as landfarming, soil washing, thermal desorption, and phytoremediation, thermal desorption can be one of the methods that has a relatively short treatment period [15]. Thermal desorption applies heat to contaminated soils, and oil components are removed via volatilization and/or desorption [16]. Thermal desorption has received increasing attention due to its advantages, such as suitability to different types of contaminants, short treatment period, high efficiency, high safety, and capability to recycle soil and contaminants [17].

Previous studies on thermal desorption of oil-contaminated soils focused on the optimization of treatment conditions such as temperature, flow rate of sweeping gas, and treatment time $[17,18]$. Also, previous studies focused on the removal efficiencies of the target compound groups such as diesel [18]. Therefore, in this study, the changes in the different oil components found in oilcontaminated soils including TPH, PAHs, Alk-PAHs, and UCM were studied and compared under different conditions of thermal desorption. Specifically, a soil sample was taken from a site where it was used to be a landfill site from 1960 to 1970 and a gas station site from 1988 to 2010, and the thermal desorption efficiencies for removal of TPH, UCM, PAHs, and Alk-PAHs were determined. The effects of factors such as moisture content, temperature, and operating time on the thermal desorption efficiency were also studied.

\section{Materials and methods}

\section{Soil characteristics}

A soil sample taken from the site A where it was used to be a landfill site followed by a gas station site were airdried and sieved through a $2 \mathrm{~mm}$ sieve. The soil sample was placed at $4{ }^{\circ} \mathrm{C}$ until being used in the experiments. The soil texture was sandy clay loam with $66 \%$ sand, $20 \%$ clay, and $14 \%$ silt. The water holing capacity (WHC) was $43 \pm 0.004 \%$, and $\mathrm{pH}$ was $6.99 \pm 0.02$. The background TPH, UCM, PAHs, and Alk-PAHs concentrations were $1965 \pm 16,1441 \pm 9,0.76 \pm 0.02$, and $61 \pm 2.1 \mathrm{mg} \mathrm{kg}^{-1}$, respectively.

\section{Thermal desorption experiments}

The thermal desorption was carried out in a muffle furnace (DMF-3 T, Lab House, Korea). Different temperatures $\left(200,400,600{ }^{\circ} \mathrm{C}\right)$ and different operation times $(15$, $30,45,60 \mathrm{~min}$ ) were used to run the thermal desorption experiments. For each sample, $10 \mathrm{~g}$ of soil were put in a ceramic plate, which was placed in the furnace. After treatment, the soil samples were removed from the furnace, and cooled down in a desiccator. All these experiments were conducted in triplicate under each condition. The removal efficiency $\left(R_{\mathrm{e}}\right)$ was calculated by using Eq. 1 .

$$
R_{\mathrm{e}}(\%)=\left(C_{0}-C / C_{0}\right) \times 100
$$

where $C_{0}$ is the initial contaminant concentration in soil $\left(\mathrm{mg} \mathrm{kg}^{-1}\right)$ and $C$ is the residual concentration of contaminant in soil after the thermal treatment $\left(\mathrm{mg} \mathrm{kg}^{-1}\right)$.

\section{Analysis of TPH, UCM, PAHs, and Alk-PAHs}

Extraction and purification of the soil samples were carried out according to the method of quantitative oil analysis method [19]. TPH, UCM, PAHs, and Alk-PAHs were extracted with $n$-hexane $(95 \%, \mathrm{~J}$. T. Baker) using a Soxhlet apparatus for $16 \mathrm{~h}$. The residual TPH and UCM concentrations in the extracts were analyzed using a gas chromatograph equipped with a flame ionization detector (GC-FID; Agilent $6890 \mathrm{~N}$, Agilent, DE, USA) with split mode (1:10) injection on a bonded phase fused silica capillary column DB-5 (Agilent J\&W, $30 \mathrm{~m} \times 0.25 \mathrm{~mm}$ i.d. $\times 0.25 \mu \mathrm{m}$ film thickness). The column temperature was kept at $40{ }^{\circ} \mathrm{C}$ for $8 \mathrm{~min}$, and ramped at $12{ }^{\circ} \mathrm{C}$ $\mathrm{min}^{-1}$ to $320{ }^{\circ} \mathrm{C}$, which was held for $20 \mathrm{~min}$. The injector and detector temperatures were kept at 250 and $320{ }^{\circ} \mathrm{C}$, respectively. The flow rate of $\mathrm{N}_{2}$ was $1 \mathrm{~mL} \mathrm{~min}{ }^{-1}$. The residual concentrations of PAHs and Alk-PAHs in the extracts were analyzed using gas chromatograph equipped with a mass spectrometry (GC-MS; Agilent 6890/HP 5973, Agilent, DE, USA) with split mode (1:10) injection on a bonded phase fused silica capillary column HP-5MS Ultra Inert $(30 \mathrm{~m} \times 0.25 \mathrm{~mm}$ i.d. $\times 0.25 \mathrm{um}$ film thickness). The column temperature was $60^{\circ} \mathrm{C}$ for $6 \mathrm{~min}$, and ramped at $6{ }^{\circ} \mathrm{C} \mathrm{min}{ }^{-1}$ to $300{ }^{\circ} \mathrm{C}$, which was held for $13 \mathrm{~min}$. The injector and detector temperatures were kept at 260 and $300{ }^{\circ} \mathrm{C}$, respectively. The flow rate of $\mathrm{He}$ was

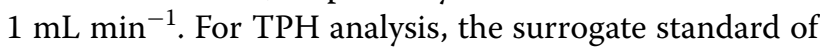
o-terphenyl and the internal standard of $5 \alpha$-androstane were used. For the analysis of PAHs and Alk-PAHs, dibenzothiophene-D8 and PAHs internal standard $5 \mathrm{mix}$ (naphthalene-D8, acenaphthene-D10, phenanthreneD10, chrysene-D12, perylene-D12) were used as the surrogate standards, and $p$-terphenyl-D14 was used as the internal standard. The standards were purchased from the Accustandard.

\section{Results and discussion Removal of TPH and UCM}

The changes in the residual concentrations of TPH and $\mathrm{UCM}$ during the thermal desorption at $200{ }^{\circ} \mathrm{C}$ are shown in Fig. 1a. The concentrations of TPH and UCM gradually decreased with time reaching the average removal 

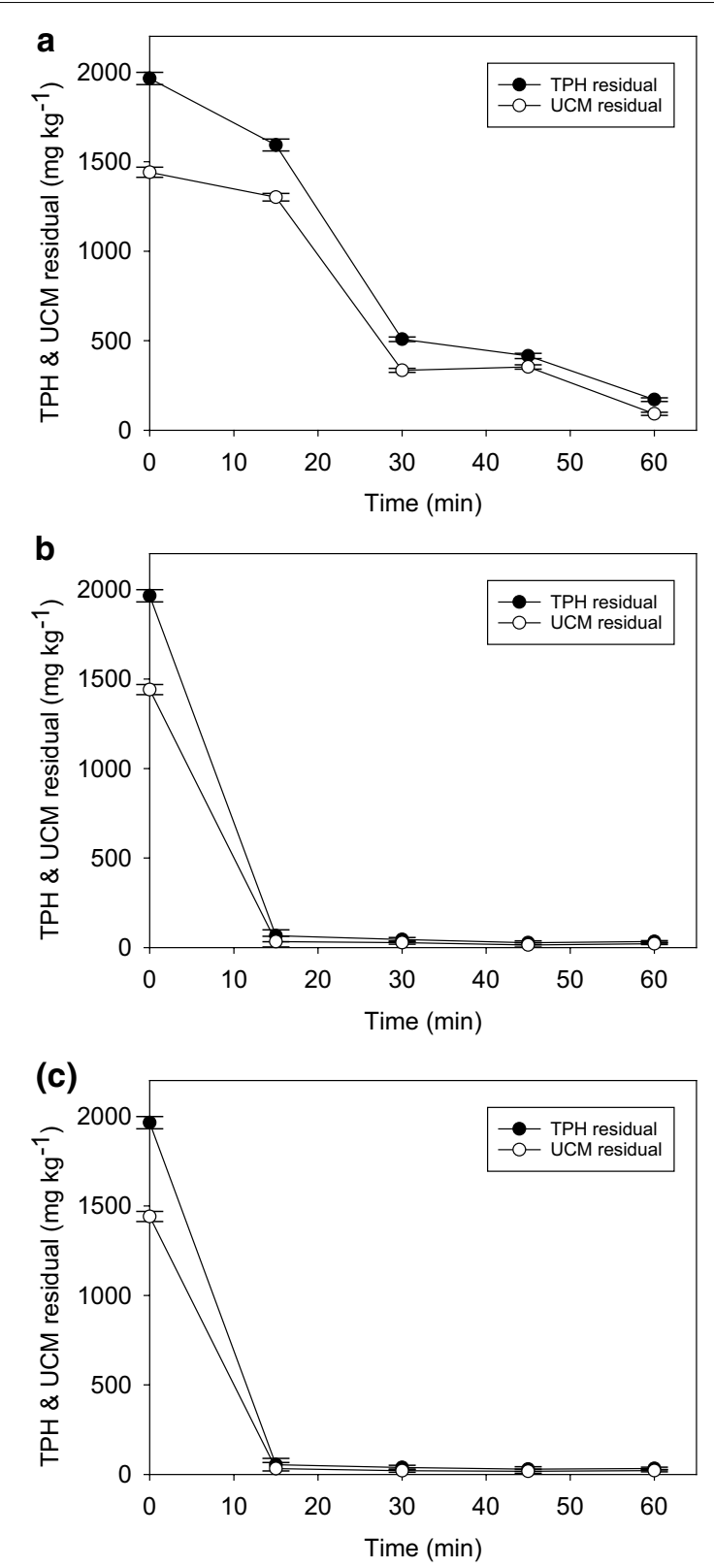

Fig. 1 Changes in the concentrations of total petroleum hydrocarbons (TPH) and unresolved complex mixtures (UCM) during the thermal desorption at $\mathbf{a} 200^{\circ} \mathrm{C}, \mathbf{b} 400{ }^{\circ} \mathrm{C}$, and $\mathbf{c} 600^{\circ} \mathrm{C}$

efficiencies of 74 and $76 \%$, respectively, after $30 \mathrm{~min}$ treatment. After 60 min treatment, the average removal efficiencies increased to $92 \%$ for TPH and $94 \%$ for UCM. Similar trends were observed at 400 and $600{ }^{\circ} \mathrm{C}$ (Fig. 1b, c). At both temperatures, almost complete removal was achieved after 15 min treatment. When the removal efficiencies after 15 min treatment at different temperatures are compared, the removal efficiency was lower at $200{ }^{\circ} \mathrm{C}$ than at higher temperatures, but the removal efficiencies

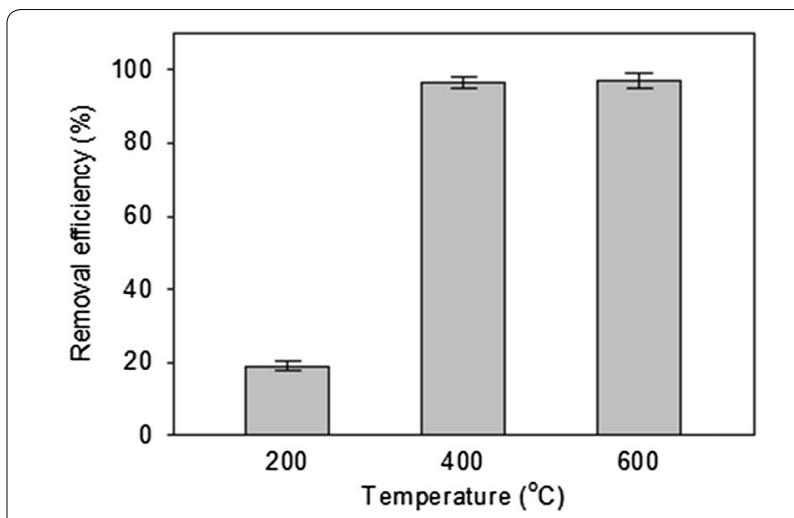

Fig. 2 Total petroleum hydrocarbons (TPH) removal efficiencies (\%) after 15 min thermal desorption treatment at different temperatures

were statistically similar at 400 and $600{ }^{\circ} \mathrm{C}$ ( $p$-value $\left.>0.05\right)$ (Fig. 2). The maximum TPH removal efficiency of $99 \%$ was obtained at 400 and $600{ }^{\circ} \mathrm{C}$ after 15 min treatment (Fig. 2). Similarly, previous studies reported comparable TPH removal efficiencies. One previous study reported $94.7 \%$ of TPH removal after 15 min thermal desorption of petroleum oil-contaminated soil (initial concentration of $5133 \pm 508 \mathrm{mg} \mathrm{kg}^{-1}$ ) at $200{ }^{\circ} \mathrm{C}$ in a rotary kiln [20]. In another study, the maximum TPH removal efficiency of about $98 \%$ was achieved at $500{ }^{\circ} \mathrm{C}$ after 15 min treatment of the combined microwave and thermal desorption processes [21].

Thermal desorption can be classified as low temperature thermal desorption or high temperature thermal desorption, and the remedial process includes the heating (direct or indirect) of the contaminated environmental matrix at an appropriate temperature in a vacuum or carrier gas system to separate target volatile or semivolatile contaminants from the matrix [22]. In thermal desorption, the boundary between high and low temperatures is not clear, but it is classified as around 300$350^{\circ} \mathrm{C}$. However, very high heating temperatures destroy the soil structure, volatilize and pyrolyze organic matter in the soil, and decompose carbonates in soil minerals, and this makes inappropriate to reuse soil after contaminant treatment and/or subsequent reclamation [23].

Figure 3 shows the GC chromatograms of the TPH and UCM. The UCM is shown as humps in the GC chromatograms [7]. In a previous study, the GC-resolved peaks of the GC chromatograms were used to determine the total GC detectable TPH, GC-resolved peaks, and UCM [24]. In the case of the raw soil sample (i.e., untreated soil sample), the amount of UCM (i.e., the area under the hump) was found to be considerably high ( $43 \%$ of the total oil content). After thermal treatment at $200{ }^{\circ} \mathrm{C}$ for 30 and $60 \mathrm{~min}$, the areas under the UCM chromatograms 


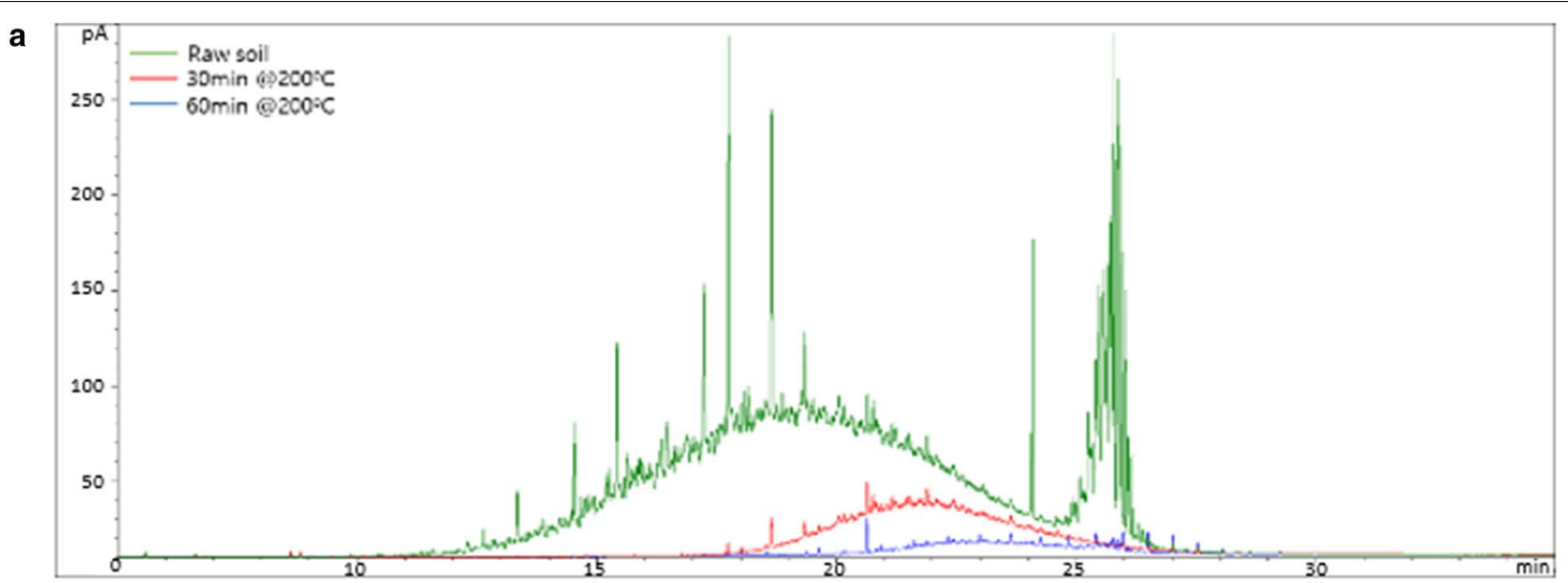

b

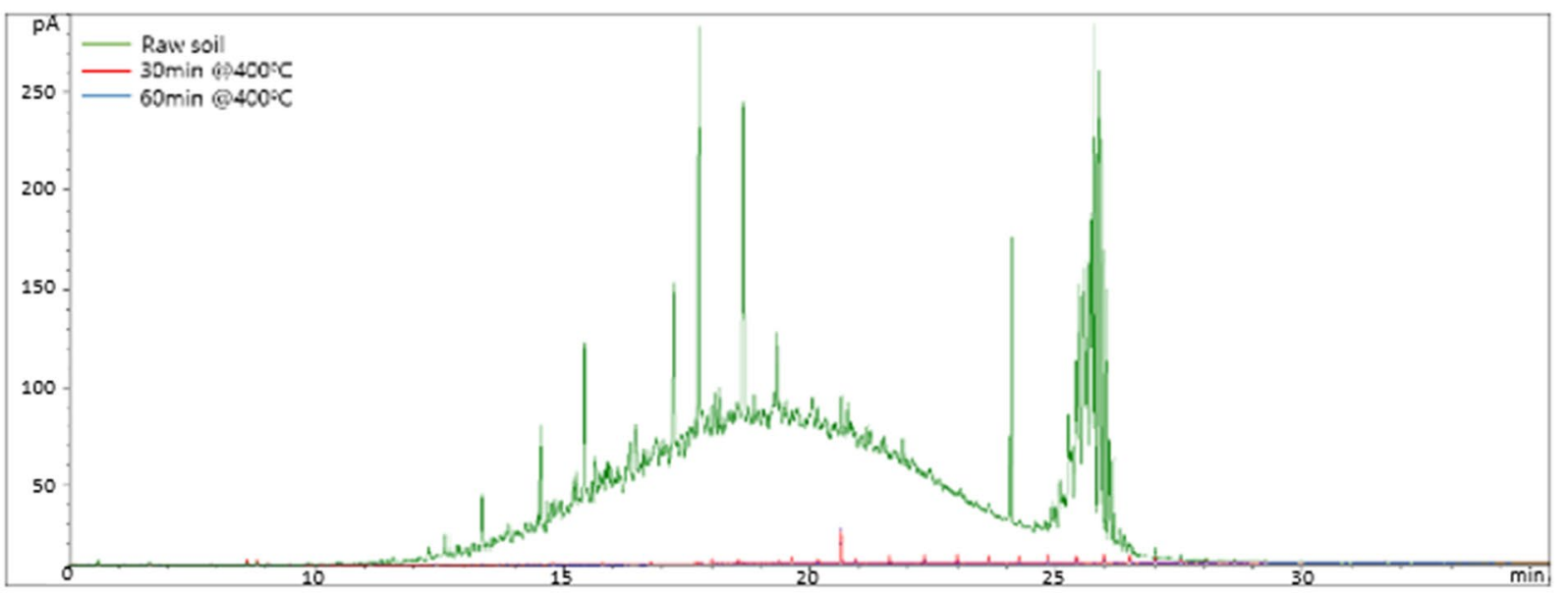

C

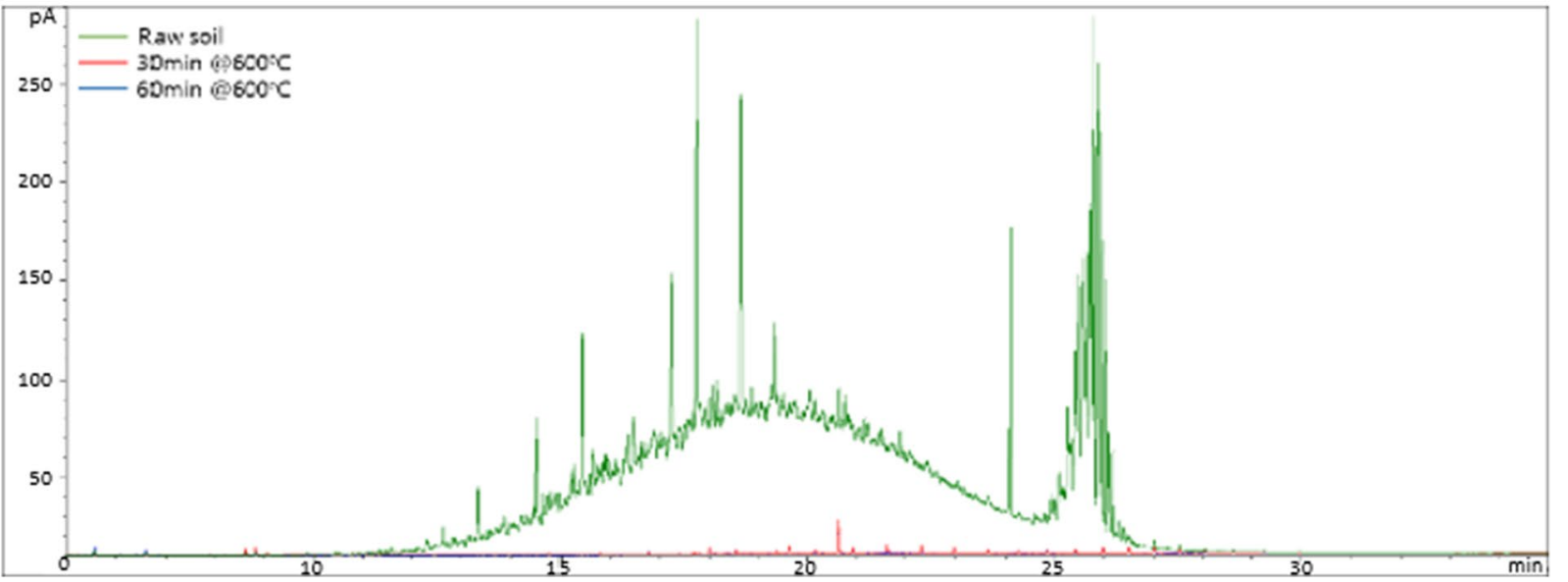

Fig. 3 Gas chromatography chromatograms of unresolved complex mixtures (UCM) and total petroleum hydrocarbons (TPH) at $\mathbf{a} 200^{\circ} \mathrm{C}, \mathbf{b} 400^{\circ} \mathrm{C}$, and $\mathbf{c} 600^{\circ} \mathrm{C}$. The green, red, and blue lines indicate the chromatograms of the raw soil, $30 \mathrm{~min}$ treated soil, and 60 min treated soil, respectively. The area under the hump is considered as the UCM

were remarkably reduced (Fig. 3a), and similar reduction in the areas under the UCM chromatograms with treatment time was also observed at 400 and $600{ }^{\circ} \mathrm{C}$ (Fig. 3b, c). The changes in the UCM concentrations are shown in Fig. 4. The removal was slower at $200{ }^{\circ} \mathrm{C}$ than at higher temperatures (Fig. 4). Almost complete UCM removal was observed after $15 \mathrm{~min}$ treatment at 400 and $600{ }^{\circ} \mathrm{C}$ (Fig. 4). The removal did not show a statistically 

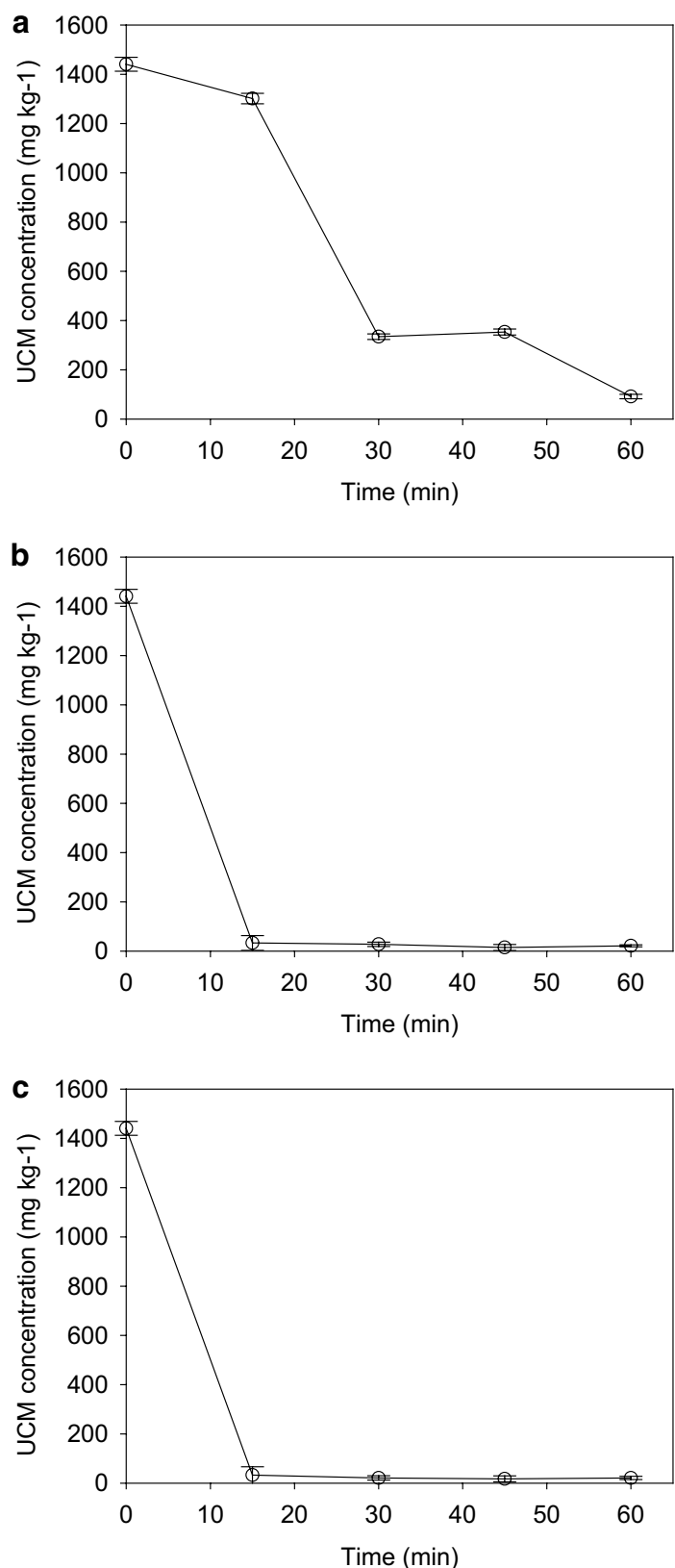

Fig. 4 Changes in the unresolved complex mixtures (UCM) concentrations during the thermal desorption treatment at $\mathbf{a} 200^{\circ} \mathrm{C}$, b $400{ }^{\circ} \mathrm{C}$, and $\mathbf{c} 600^{\circ} \mathrm{C}$

significant difference between the treatment temperatures of 400 and $600{ }^{\circ} \mathrm{C}$ ( $p$-value $\left.>0.05\right)$. Recent studies on UCM tried to analyze the UCM hydrocarbons and investigated the biodegradation potential of UCM hydrocarbons $[24,25]$. Also, a reduction in UCM was observed during the bioremediation of PAHs-contaminated soil [26]. However, studies on UCM removal from oil-contaminated soils are limited.
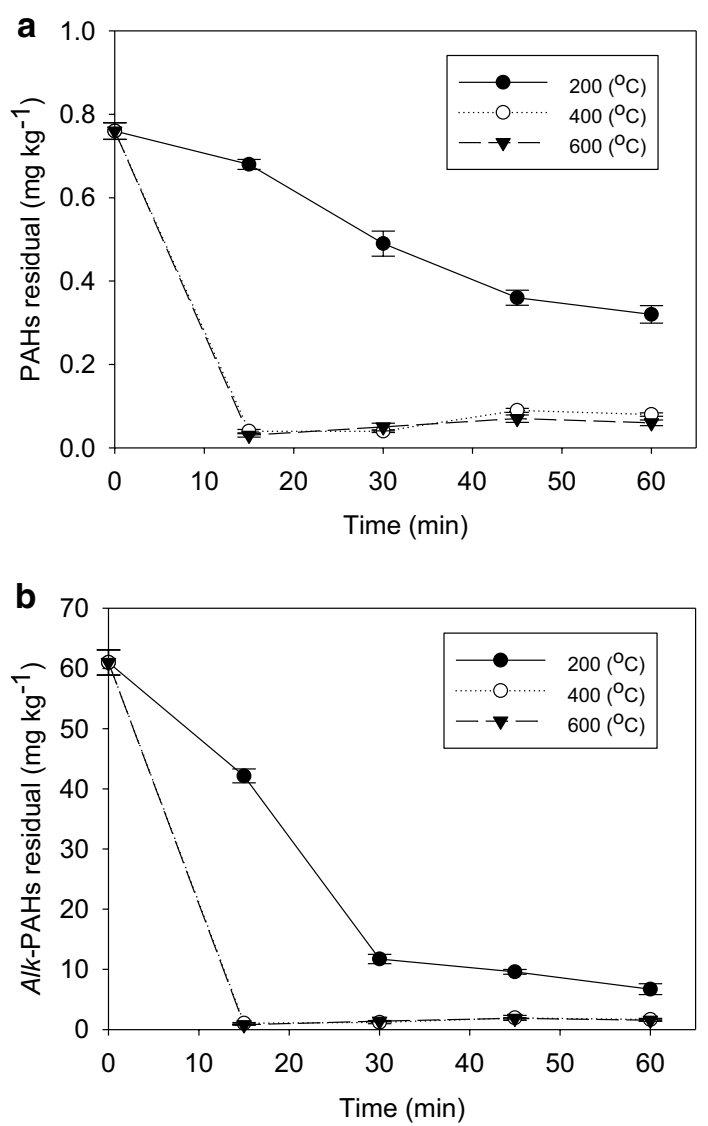

Fig. 5 Changes in the concentrations of a polyaromatic hydrocarbons (PAHs) and $\mathbf{b}$ alkylated polyaromatic hydrocarbons (Alk-PAHs) in the oil-contaminated soil during the thermal desorption treatment at different concentrations

\section{Removal of PAHs and Alk-PAHs}

The changes in the PAHs and Alk-PAHs concentrations during the thermal desorption treatment at different temperatures are shown in Fig. 5. The initial PAHs concentration was a trace amount (1.2\% of the total oil content) compared to other components (e.g., TPH, UCM). The removal efficiency of PAHs increased with increasing temperature from 200 to $400{ }^{\circ} \mathrm{C}$, but no further increase was observed with further increase in temperature to $600{ }^{\circ} \mathrm{C}$ (Fig. 5a). For example, after $15 \mathrm{~min}$ treatment, the average removal efficiencies were 32,96 , and $97 \%$ at 200 , 400 , and $600{ }^{\circ} \mathrm{C}$, respectively. Alk-PAHs were reduced by $39 \%$ to $42 \mathrm{mg} \mathrm{kg}^{-1}$ after $15 \mathrm{~min}$ treatment at $200{ }^{\circ} \mathrm{C}$, and by $90 \%$ to $6.7 \mathrm{mg} \mathrm{kg}^{-1}$ after $60 \mathrm{~min}$ treatment at $200{ }^{\circ} \mathrm{C}$ (Fig. 5b). At $400{ }^{\circ} \mathrm{C}, 98 \%$ was removed after 15 min treatment, while $99 \%$ was removed after 15 min treatment at $600{ }^{\circ} \mathrm{C}$. Previous study showed similarly high PAHs removal at higher temperatures. For example, when PAHs were removed using thermal incineration at temperatures from 870 to $1200{ }^{\circ} \mathrm{C}$, the removal efficiency 
was $>90 \%$, and the removal of PAHs using an indirect heating type thermal desorption device at a temperature of $>450{ }^{\circ} \mathrm{C}$ showed $99.9 \%$ removal efficiency after $1 \mathrm{~h}$ [27].

\section{Acknowledgements \\ Not applicable.}

\section{Author's contributions}

All authors designed the experiments together, and $\mathrm{SL}$ and $\mathrm{BC}$ conducted the experiments. BC, SL and EHJ analyzed and interpreted the results, and prepared the manuscript. All authors read and approved the final manuscript.

\section{Funding}

This study was also supported by the National Research Foundation of Korea (NRF-2018R1C1B6002702).

\section{Availability of data and material}

The datasets used and/or analyzed during the current study are available from the corresponding author on reasonable request.

\section{Compliance with ethical standards}

\section{Competing interests}

The authors declare no conflict of interest.

\section{Author details}

1 Department of Environmental Science, Hankuk University of Foreign Studies, 81 Oedae-ro, Mohyeon-eup, Cheoin-gu, Yongin-si, Gyeonggi 17035, South Korea. ${ }^{2}$ Department of Agricultural and Biological Chemistry, Chonnam National University, 77 Yongbong-ro, Buk-gu, Gwangju 61186, South Korea.

Received: 27 October 2020 Accepted: 25 November 2020

Published online: 05 December 2020

\section{References}

1. Zhang Z, Hou Z, Yang C, Ma C, Tao F, Xu P (2011) Degradation of n-alkanes and polycyclic aromatic hydrocarbons in petroleum by a newly isolated Pseudomonas aeruginosa DQ8. Bioresour Technol 102:4111-4116

2. Greekdrink MJ, Van Loosdrecht MCM, Luyben K, Ch AM (1996) Biodegradability of diesel oil. Biodegradation 7:73-81

3. Xu J, Xin L, Huang T, Chang K (2011) Enhanced bioremediation of oil contaminated soil by graded modified Fenton oxidation. J Environ Sci 23:1873-1879

4. Abdel-Shafy HI, Mansour MSM (2016) A review on polycyclic aromatic hydrocarbons: source, environmental impact. effect on human health and remediation. Egypt J Pet 25:107-123

5. Lors C, Ryngaert A, Périé F, Diels L, Damidot D (2010) Evolution of bacterial community during bioremediation of PAHs in a coal tar contaminated soil. Chemosphere 81:1263-1271

6. Skoczynska E, Boer JD (2019) Retention behaviour of alkylated and non-alkylated polycyclic aromatic hydrocarbons on different types of stationary phases in gas chromatography. Separations 6:7-12

7. Frysinger GS, Gaines RB, Xu L, Reddy CM (2003) Resolving the unresolved complex mixture in petroleum-contaminated sediments. Environ Sci Technol 37:1653-1662

8. Du J, Mehler WT, Lydy MJ, You J (2012) Toxicity of sediment-associated unresolved complex mixture and its impact on bioavailability of polycyclic aromatic hydrocarbons. J Hazard Mater 203-204:169-175
9. Jho EH, Ryu H, Shin D, Kim YJ, Choi YJ, Nam K (2014) Prediction of landfarming period using degradation kinetics of petroleum hydrocarbons: test with artificially contaminated and field-aged soils and commercially available bacterial cultures. J Soils Sediments 14:138-145

10. Hong JK, Jho EH, Choi HS, Kang G (2018) Role of hemoglobin in hemoglobin-based remediation of the crude oil-contaminated soil. Sci Total Environ 627:1174-1181

11. Kim T, Hong JK, Jho EH, Kang G, Yang DJ, Lee SJ (2019) Sequential biowashing-biopile processes for remediation of crude oil contaminated soil in Kuwait. J Hazard Mater 378:120710

12. Vasudevan N, Rajaram P (2001) Bioremediation of oil sludge-contaminated. Environ Int 26:409-411

13. Wang S, Wang X, Zhang C, Li F, Guo G (2016) Bioremediation of oil sludge contaminated soil by landfarming with added cotton stalks. Int Biodeterior Biodegradation 106:150-156

14. Alessandra CO, Spinelli C, Mario TK, Edmilson SL, Gavazza S (2012) Bioremediation of a tropical clay soil contaminated with diesel oil. J Environ Manage 113:510-516

15. Lee WB, Park SH, Kim JO, Kim SU (2010) Remediation technology using media for soil contaminated with oil. J Kor Soc Waste Manage 24:498-502

16. Vidonish JE, Zygourakis K, Masiello CA, Sabadell G, Alvarez PJ (2016) Thermal treatment of hydrocarbon-impacted soils: a review of technology innovation for sustainable remediation. Engineering 2:426-437

17. Lee JK, Kim BU, Park D (1999) Thermal treatment of petroleum contaminated soils by a fluidized bed desorber. Korean J Chem Eng 16:684-687

18. Zivdar Z, Heidarzadeh N, Asadollahfardi G (2019) Remediation of dieselcontaminated soil by low-temperature thermal desorption. Int J Environ Sci Technol 16:6113-6124

19. USEPA (1999) Method 1664 Revision a: N-hexane extractable material and silica gel treated $\mathrm{n}$-hexane extractable material by extraction and gravimetry. United States Environmental Protection Agency, Washington DC

20. Yi YM, Park SY, Munster C, Kim GK, Sung KJ (2016) Changes in ecological properties of petroleum oil-contaminated soil after low-temperature thermal desorption treatment. Water Air Soil Pollut 227:108

21. Ha SA, Choi KS (2010) A study of a combined microwave and thermal desorption process for contaminated soil. Environ Eng Res 15:225-230

22. Falciglia PP, Lumia L, Giustra MG, Gagliano E, Roccaro P, Vagliasindi FGA, Bella GD (2020) Remediation of petrol hydrocarbon-contaminated marine sediments by thermal desorption. Chemosphere 260:127576

23. Zhao C, Dong Y, Feng Y, Li Y, Dong Y (2019) Thermal desorption for remediation of contaminated soil: a review. Chemosphere 221:841-855

24. Ramadass K, Kuppusamy S, Venkateswarlu K, Naidu R, Naidu M (2020) Unresolved complex mixtures of petroleum hydrocarbons in the environment: an overview of ecological effects and remediation approaches. Crit Rev Environ Sci. Technol. https://doi.org/10.1080/10643389.2020.1813066

25. Maity JP, Huang YH, Lin HF, Chen CY (2020) Variation of microbial diversity in catastrophic oil spill area in marine ecosystem and hydrocarbon degradation of UCMs (unresolved complex mixtures) by marine indigenous bacteria. Appl Biochem Biotechnol. https://doi.org/10.1007/s12010-02003335-5

26. Pelaez Al, Lores I, Sotres A, Mendez-Garcia C, Fernandez-Velarde C, Santos JA, Gallego JLR, Sanchez J (2013) Design and field-scale implementation of an "on site" bioremediation treatment in PAH-polluted soil. Environ Pollut 181:190-199

27. Gan S, Lau EV, Ng HK (2009) Remediation of soils contaminated with polycyclic aromatic hydrocarbons (PAHs). J Hazard Mater 172:532-549

\section{Publisher's Note}

Springer Nature remains neutral with regard to jurisdictional claims in published maps and institutional affiliations. 